Article

\title{
Smallholder Farmers' Perspectives on Advisory Extension Services: A Case Study of the Gamo Communities of Southern Ethiopia
}

\author{
Miki Dowsing * and Sarah Cardey \\ School of Agriculture, Policy and Development, University of Reading, Reading RG6 6AR, UK; \\ s.p.cardey@reading.ac.uk \\ * Correspondence: m.dowsing@pgr.reading.ac.uk
}

Received: 8 July 2020; Accepted: 2 September 2020; Published: 11 September 2020

check for updates

\begin{abstract}
This is a case study-based research project investigating the status of Advisory Extension Services in southern Ethiopia. The goal was to determine whether available service provisions meet the requirements of smallholder farmers and enabled them to improve their farming practices and livelihoods. A combination of an exploratory inductive approach and mixed methods was used (e.g., questionnaire survey, focus group discussions, key informant interviews). Participants included members of farming households, and agents, experts, and providers working in the agricultural rural sector. The key findings suggested that limited access to resources and unpredictable environmental conditions were stifling smallholder farmer innovation and livelihoods. Service provisions should be better tailored to local conditions, provide greater resource access, and work more closely with farmers. The development and implementation of service provision should involve a wide range of institutions and farmers throughout the process. Local community- and farmer-based organisations are especially important, and can work alongside innovative and talented farmers to enable more effective dissemination of information. Agricultural rural development and service provision should focus greater attention on the views and perspectives of farmers from a range of areas with differing socio-demographic and agro-ecological characteristics for comparative analysis.
\end{abstract}

Keywords: Advisory Extension Services; smallholder farmers; agriculture rural development; livelihood development; Ethiopia

\section{Introduction}

Effective service provision is essential in meeting the needs of the clients (i.e., smallholder farmers) and the challenges they face from ongoing changes in their environment and situations. Access to appropriate advice and service provision is especially vital for those living in rural areas whose lives depend on subsistence smallholder farming. There are a range of mechanisms for providing services to farmers, with different conceptualizations of "service provision". One of these is Advisory Extension Services (AES, hereafter) ${ }^{1}$. AES takes into account the systems, context and knowledge exchanges to support farming practices.

AESs are aimed at delivering information, knowledge, and technology to clients, and the overall goal of such institutions is to enable their clients to improve their situation (Anderson and Feder 2004; Swanson et al. 1998; Rajalahti and Swanson 2010). In an ideal scenario, service providers should be

1 For the purposes of this research project, the term 'AES' is used as a synonym for 'Advisory Extension Services', and along with terms 'Advisory Services' and 'Extension Services', are often interchangeably used for service provisions across the range of sectors. 
accountable to their clients and provide advice and information which helps them to make decisions and solve problems more effectively (Oakley and Garforth 1997). Certain conditions are necessary for AES to be able to function effectively. Zuurbier (1984, p. 13, 167; cited in Röling $(1988$, p. 39)) described the core elements of extension (intervention and communication) as instruments of change, but pointed out that they were effective only when adopted voluntarily, and required targeted processes to be deployed by the institution. It has also been said that extension should be an informal educational process for clients that provides advice, thus enabling them to solve problems by making informed decisions (Oakley and Garforth 1997; Poulton et al. 2010; Swanson et al. 1998). The authors stressed the need for a number of basic processes of learning, dialogue, and adoption to occur at different stages of AES, the four main focuses of which should be: Knowledge and skills; technical advice and information; motivation and self-confidence; and farmer organisation.

There has been a focus on the importance of AES management and processes (such as participation, assessment, and evaluation) along with the need to consider efficient and effective means of disseminating provisions, and these have become an important and integral part of the overall operations (Christoplos et al. 2012; Faure et al. 2016; Rajalahti and Swanson 2010). Such aspects include a participatory approach ${ }^{2}$ to assessing, monitoring, and evaluating AESs, which has evolved since the 1990s (Biggs 2008; Rajalahti et al. 2005).

A range of performance elements are associated with the overall goals and objectives of AES programmes/projects (Benin and Johnson 2008; Birner et al. 2009; European Commission 2006; Faure et al. 2016; Martin et al. 2011). These include:

- Content (accuracy and relevancy of advice),

- timeline (duration and availability),

- feedback (availability and mode of communication),

- relevance (meeting the needs and requirements for recipients/participants),

- targeting (appropriacy for recipients/participants),

- efficiency (of results obtained against resources invested), and

- $\quad$ effectiveness (achievement of objectives).

Furthermore, the operations and processes of AESs are becoming more participatory in approach (Christoplos et al. 2012; Faure et al. 2016; Rajalahti and Swanson 2010), so that smallholder farmers should be able to play an important role. Their participation in AESs has been examined by a number of authors based on a breakdown of methods and schema divided into categories of contracted, consultative, collaborative, or collegiate modes (Biggs 1989, pp. 3-4, see Footnote no 4). Hence, the pathways and scaling of AES should be disseminated beyond participants in order to have a positive impact on long-term sustainability which could lead to improvements in capacity, network building, collective action, and competencies at local levels (Pretty 1995; Wigboldus and Leeuwis 2013).

Under previous regimes, the Government of Ethiopia $(\mathrm{GoE})$ implemented numerous policies and reforms via development programmes predominantly focused on agrarian and rural development since being introduced in the 1950s (ATA and MoA 2014; Kassa 2008; Rahmato 1984). Under the federal government, the Ethiopian People's Revolutionary Democratic Front (EPRDF, in power since 1991), the country's policy directions and strategies have made agriculture-centred development and the elimination of rural poverty a high priority in the hope of improving overall economic development, securing social justice, and becoming a middle-income country (ATA 2017a, 2017b; Kassa 2008). During the 1990s, the decentralisation process began as part of the regionalisation of activities (Berhanu 2012; Fenta and Assefa 2009). Since 2010, the GoE (overseen by the Ministry of

2 Examples include Farmer Participatory Research (FPR), Participatory Action Research (PAR), Participatory Technology Development (PTD), Farmer-led Participatory Innovation/Participatory Innovation Development (PID) and the Participatory Learning and Action (PLA) system. 
Agriculture and Natural Resources (MoANR 2017)) has reviewed and renewed national strategies for the Participatory Extension System (PES), in conjunction with the Growth and Transformation Plan (GTP) and the Agricultural Sector Policy and Investment Framework (PIF) (ATA and MoA 2014).

The Gamo Highlands are located in southern Ethiopia, within the Southern Nations', Nationalities' and Peoples' Region (SNNPR), $500 \mathrm{~km}$ (270 miles) south of Addis Ababa. The traditional farming and food system of the area (a combination of livelihood, agricultural biodiversity, and agro-forestry and -ecological practices) is thought to date back over 10,000 years. The heterogeneous landscape of the Highlands (a patchwork of trees, shrubs, bamboo groves, and pastures) has been carefully organised through this system, where forestry and livestock management are practised alongside a high diversity of crop plant farming (Bayu 2012; CBD 2014; Samberg et al. 2010).

In the case of Ethiopia, despite sector administration being increasingly decentralised to local and regional levels, AESs have been more successfully implemented in certain regions than others (Gebremedhin et al. 2006). The GoE's AES strategy has also attempted to focus on modernisation and industry-led development intended to transform the agricultural sector from subsistence farming into a commercial and market-focused industry. However, even smallholder farmers often struggle to produce enough for their own consumption, and such a shift could be one threat to smallholder farmers, especially those living in rural highlands. Therefore, AES must increase their focus on specific aspects relevant to rural farming households and communities (such as availability of crops and plants; the importance of biodiversity and conservation; or smallholder farmers' reliance on their own produce).

In the literature of AES, research projects have mainly investigated from the viewpoint of service-providers rather than the participants (i.e., smallholder farmers), but as services have become increasingly decentralised, participatory, and evidence-based, continuous investigation is necessary to understand specific scenarios.

The goal of the research project was to explore a range of areas and components of AES, and investigate whether they meet the requirements of smallholder farmers and enable them to improve their farming practices and livelihoods effectively. The research objectives and related questions examined AES characteristics and procedures, and the nature and extent of smallholder farmers' participation. Potential alternative approaches, methods, and options were also investigated.

\section{Results}

\subsection{Advisory Extension Services-Access, Participation, Service Delivery, and Impact}

\subsubsection{Presence of and Access to Advisory Extension Services}

The AES present in the case study locations were provided by a combination of government (public), Civil Society Organisations/Non-Governmental Organisations (CSOs/NGOs), and Community-/Farmer-Based Organisations (CBOs/FBOs) (Tables 1-4). There were no service provisions from research institutions or private companies active in either case study district.

The vast majority of respondents (90.5\%) reported having received AES of some kind, although AESs provided by institutions such as $\mathrm{CSO}$ /NGOs varied from village to village. Informal channels of access existed, but were not much in evidence during the fieldwork, and smallholder farmers tended to obtain services through formal mechanisms. 
Table 1. Advisory Extension Services (AES) in the Case Study Locations (Questionnaire Survey).

\begin{tabular}{|c|c|c|c|c|c|c|c|c|}
\hline \multirow{3}{*}{ Service-Providing Sector } & \multicolumn{8}{|c|}{ Number of Advisory Extension Service Active in Each Area } \\
\hline & \multicolumn{4}{|c|}{ Case Study District One } & \multicolumn{4}{|c|}{ Case Study District Two } \\
\hline & Village 1.1 & Village 1.2 & Village 1.3 & District One Total & Village 2.1 & Village 2.2 & Village 2.3 & District Two Total \\
\hline Government (Public) & 2 & 3 & 2 & 7 & 3 & 3 & 3 & 9 \\
\hline $\begin{array}{c}\text { Civil Society } \\
\text { Organisations/Non-Governmental } \\
\text { Organisations }\end{array}$ & 2 & 2 & 2 & 6 & 5 & 1 & 4 & 10 \\
\hline Private & 0 & 0 & 0 & 0 & 0 & 0 & 0 & 0 \\
\hline $\begin{array}{c}\text { Community-/Farmer-based } \\
\text { Organisations }{ }^{1}\end{array}$ & 0 & 0 & 0 & 0 & 0 & 1 & 0 & 1 \\
\hline Cultural/religious Organisations & 1 & 1 & 1 & 3 & 1 & 1 & 1 & 3 \\
\hline Total & 5 & 6 & 5 & 16 & 9 & 6 & 8 & 23 \\
\hline
\end{tabular}

N.B. ${ }^{1}$ Excluding cultural and religious organisations.

Table 2. Types of Advisory Extension Service received ${ }^{1}$ by Smallholder Farmers (Questionnaire Survey). Responses categorised by Case Study District.

\begin{tabular}{|c|c|c|c|c|c|c|c|c|c|c|c|c|}
\hline \multirow[b]{3}{*}{ Service-providing Sectors } & \multicolumn{10}{|c|}{ Number of Respondents Who Reported Receiving Advisory Extension Service of Each Type in Each Area } & \multirow[b]{3}{*}{$\begin{array}{c}\text { Grand } \\
\text { Total }\end{array}$} & \multirow[b]{3}{*}{$\begin{array}{l}\text { \% of Grand Total } \\
\text { District Response }\end{array}$} \\
\hline & \multicolumn{5}{|c|}{ Case Study District One } & \multicolumn{5}{|c|}{$\begin{array}{c}\text { Case Study District Two } \\
\end{array}$} & & \\
\hline & $\begin{array}{l}\text { Village } \\
1.1\end{array}$ & $\begin{array}{l}\text { Village } \\
1.2\end{array}$ & $\begin{array}{l}\text { Village } \\
1.3\end{array}$ & $\begin{array}{c}\text { District } \\
\text { One-Total }\end{array}$ & $\begin{array}{c}\text { District One-\% of } \\
\text { Total District } \\
\text { Response } \\
\end{array}$ & $\begin{array}{l}\text { Village } \\
2.1\end{array}$ & $\begin{array}{l}\text { Village } \\
2.2\end{array}$ & $\begin{array}{l}\text { Village } \\
2.3\end{array}$ & $\begin{array}{c}\text { District } \\
\text { Two-Total }\end{array}$ & $\begin{array}{c}\text { District Two-\% of } \\
\text { Total District } \\
\text { Response } \\
\end{array}$ & & \\
\hline Government (Public) & 46 & 54 & 37 & 137 & $71.73 \%$ & 34 & 31 & 35 & 100 & $64.10 \%$ & 237 & $68.30 \%$ \\
\hline $\begin{array}{c}\text { Civil Society } \\
\text { Organisations/Non-Governmental } \\
\text { Organisations }\end{array}$ & 22 & 12 & 4 & 38 & $19.90 \%$ & 20 & 0 & 3 & 23 & $14.74 \%$ & 61 & $17.58 \%$ \\
\hline Private & 0 & 0 & 0 & 0 & $0 \%$ & 0 & 0 & 0 & 0 & $0 \%$ & 0 & $0 \%$ \\
\hline $\begin{array}{l}\text { Product Safety Net Programme (PSNP, } \\
\text { government-led programme) }\end{array}$ & 1 & 0 & 0 & 1 & $0.52 \%$ & 1 & 3 & 1 & 5 & $3.21 \%$ & 6 & $1.73 \%$ \\
\hline Indirect/Informal & 0 & 2 & 0 & 2 & $1.05 \%$ & 1 & 0 & 0 & 1 & $0.64 \%$ & 3 & $0.86 \%$ \\
\hline $\begin{array}{c}\text { Community-/Farmer-based } \\
\text { Organisations }^{2}\end{array}$ & 3 & 0 & 0 & 3 & $1.57 \%$ & 4 & 0 & 0 & 4 & $2.56 \%$ & 7 & $2.02 \%$ \\
\hline Others, visit and exchanges & 0 & 0 & 0 & 0 & $0 \%$ & 0 & 0 & 0 & 0 & $0 \%$ & 0 & $0 \%$ \\
\hline No Advisory Extension Service & 4 & 2 & 4 & 10 & $5.24 \%$ & 7 & 10 & 6 & 23 & $14.74 \%$ & 33 & $9.51 \%$ \\
\hline Advisory Extension Service-Total & 72 & 68 & 41 & 181 & $94.76 \%$ & 60 & 34 & 39 & 133 & $85.26 \%$ & 314 & $90.49 \%$ \\
\hline Total number of responses & 76 & 70 & 45 & 191 & & 67 & 44 & 45 & 156 & & 347 & \\
\hline
\end{tabular}

N.B. ${ }^{1}$ Some respondents reported participating in more than one type of AES; therefore, figures shown represent the number of responses, not participants. Smallholder farmers' responses were based on their participation in AES over a period of one year prior to the fieldwork. ${ }^{2}$ Excluding cultural/religious organisations (informal traditional community-level group). 
Table 3. Types of Advisory Extension Service received ${ }^{1}$ by Smallholder Farmers (Questionnaire Survey). Responses categorised by Gender.

\begin{tabular}{|c|c|c|c|c|}
\hline \multirow{2}{*}{ Service-Providing Sectors } & \multicolumn{4}{|c|}{ Number of Respondents Who Reported Receiving Advisory Extension Service of Each Type by Gender } \\
\hline & Female & $\%$ of Total Female Response & Male & \% of Total Male Response \\
\hline Government (Public) & 116 & $68.24 \%$ & 121 & $68.36 \%$ \\
\hline $\begin{array}{c}\text { Civil Society } \\
\text { Organisations/Non-Governmental Organisations }\end{array}$ & 25 & $14.71 \%$ & 36 & $20.34 \%$ \\
\hline Private & 0 & $0 \%$ & 0 & $0 \%$ \\
\hline $\begin{array}{c}\text { Product Safety Net Programme (PSNP, } \\
\text { government-led programme) }\end{array}$ & 3 & $1.76 \%$ & 3 & $1.69 \%$ \\
\hline Indirect/Informal & 3 & $1.76 \%$ & 0 & $0 \%$ \\
\hline Community-/Farmer-based Organisations $^{2}$ & 1 & $0.59 \%$ & 6 & $3.39 \%$ \\
\hline Others, visit and exchanges & 0 & $0 \%$ & 0 & $0 \%$ \\
\hline No Advisory Extension Service & 22 & $12.94 \%$ & 11 & $6.21 \%$ \\
\hline Advisory Extension Service-Total & 148 & $87.06 \%$ & 166 & $93.79 \%$ \\
\hline Total number of responses & 170 & & 177 & \\
\hline
\end{tabular}

N.B. ${ }^{1}$ Some respondents reported participating in more than one type of AES; therefore, figures shown represent the number of responses, not participants. Smallholder farmers' responses were based on their participation in AES over a period of one year prior to the fieldwork. ${ }^{2}$ Excluding cultural/religious organisations (informal traditional community-level group).

Table 4. Types of Advisory Extension Service received ${ }^{1}$ by Smallholder Farmers (Questionnaire Survey). Responses categorised by Agroecological classification ${ }^{2}$.

\begin{tabular}{|c|c|c|c|c|c|c|}
\hline \multirow[b]{2}{*}{ Service-Providing Sectors } & \multicolumn{6}{|c|}{ Number of Respondents Who Reported Receiving Advisory Extension Service of Each Type by Agroecological Classification ${ }^{2}$} \\
\hline & Highland & $\begin{array}{l}\% \text { of Total Highland } \\
\text { Response }\end{array}$ & Lowland & $\begin{array}{l}\% \text { of Total Lowland } \\
\text { Response }\end{array}$ & Midland & $\begin{array}{l}\text { \% of Total Midland } \\
\text { Response }\end{array}$ \\
\hline Government (Public) & 71 & $63.39 \%$ & 77 & $64.17 \%$ & 89 & $77.39 \%$ \\
\hline $\begin{array}{c}\text { Civil Society Organisations/Non-Governmental } \\
\text { Organisations }\end{array}$ & 24 & $21.43 \%$ & 22 & $18.33 \%$ & 15 & $13.04 \%$ \\
\hline Private & 0 & $0 \%$ & 0 & $0 \%$ & 0 & $0 \%$ \\
\hline $\begin{array}{c}\text { Product Safety Net Programme (PSNP, } \\
\text { government-led programme) }\end{array}$ & 1 & $0.89 \%$ & 4 & $3.33 \%$ & 1 & $0.87 \%$ \\
\hline Indirect/Informal & 1 & $0.89 \%$ & 0 & $0 \%$ & 2 & $1.74 \%$ \\
\hline Community-/Farmer-based Organisations ${ }^{3}$ & 4 & $4 \%$ & 3 & $2.50 \%$ & 0 & $0 \%$ \\
\hline Others, visit and exchanges & 0 & $0 \%$ & 0 & $0 \%$ & 0 & $0 \%$ \\
\hline No Advisory Extension Service & 11 & $9.82 \%$ & 14 & $11.67 \%$ & 8 & $6.96 \%$ \\
\hline Advisory Extension Service-Total & 101 & $90.18 \%$ & 106 & $88.33 \%$ & 107 & $93.04 \%$ \\
\hline Total number of responses & 112 & & 120 & & 115 & \\
\hline
\end{tabular}

N.B. ${ }^{1}$ Some respondents reported participating in more than one type of AES; therefore, figures shown represent the number of responses, not participants. Smallholder farmers' responses were based on their participation in AES over a period of one year prior to the fieldwork. ${ }^{2}$ Agroecological classification: Lowland, altitude $500-1300 \mathrm{~m}$ above sea level, Midland, altitude 1300-2200 m above sea level, and Highland, altitude above $2200 \mathrm{~m}$ above sea level. ${ }^{3}$ Excluding cultural/religious organisations (informal traditional community-level group). 


\subsubsection{Smallholder Farmers' Participation in Advisory Extension Services}

Smallholder farmers' participation in AESs was analysed using the modes outlined by Biggs (1989, pp. 3-4), dividing participation types into four categories: Contracted, consultative, collaborative, or collegiate ${ }^{3}$. During the FGD\&A, participants identified the modes of participation that best fit their experience, based on an explanation of each category provided (Figure 1a,b). A comparison of these indicated that government-led AESs were commonly delivered through either the consultative mode (i.e., in consultation with participants) or the collaborative mode (i.e., in partnership with providers and participants) consultative and collaborative. The situation was slightly different for AESs provided by CSOs/NGOs, as some of these were delivered through the collegiate mode (i.e., facilitated by the providers), as well as the consultative and collaborative modes and, in some cases, a combination of consultative and collaborative methods.

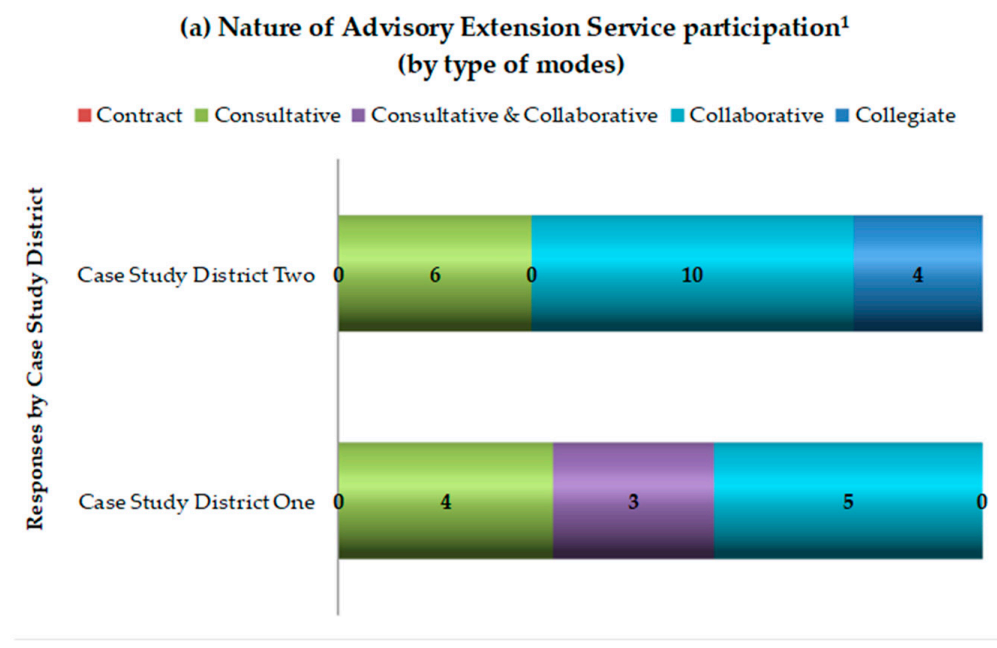

(b) Nature of Advisory Extension Service participation ${ }^{1}$ (by type of modes)

mContract $n$ Consultative $\square$ Consultative \& Collaborative $n$ Collaborative $\square$ Collegiate

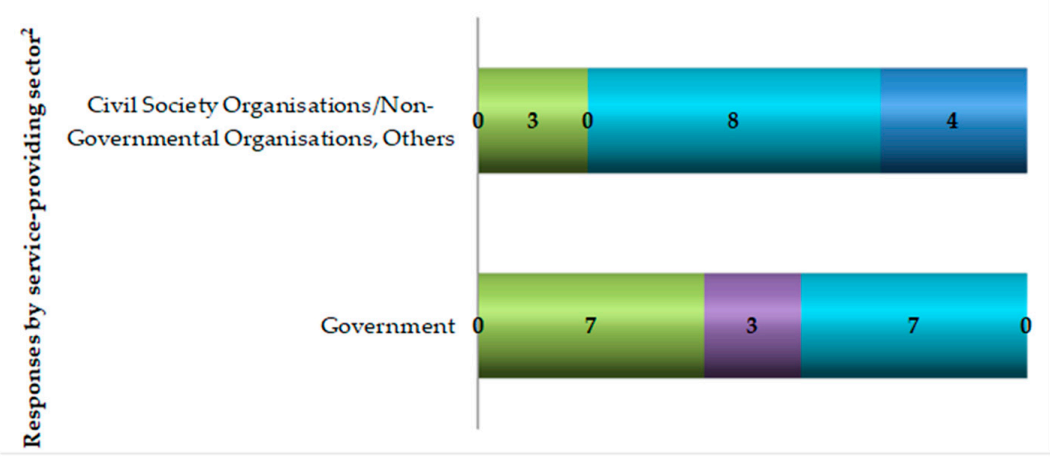

Figure 1. Mode of participation in Advisory Extension Services ${ }^{1}$ as reported by smallholder farmers (Focus Group Discussion and Activity). (a) Responses categorised by Case Study District. (b) Response categorised by service-providing sector. N.B. ${ }^{1}$ See Footnote no. $3 .{ }^{2}$ Service-providing sector, Others include cultural/religious organisations.

3 There are four types of participation, for each of which there is a different type of relationship between provider and receiver. Biggs (1989, pp. 3-4) defined these as: Contract (advice and service delivered by provider), consultative (advice and service decided in consultation with the provider), collaborative (partnership between provider and receiver), and collegiate (in which the provider's position is that of facilitator). 
2.1.3. Smallholder Farmers' Responses Concerning Service Delivery and the Impact of Advisory Extension Services

A number of performance variables ${ }^{4}$ are incorporated by service providers to evaluate AES delivery (Birner et al. 2009; European Commission 2006; Faure et al. 2016; Martin et al. 2011). See introduction for the outline of these variables. Smallholder farmers were asked to identify relevant variables in relation to AES delivery (Figure 2(a1,a2,b1,b2)). Feedback, Timeline, and Relevance were identified by respondents as the most important variables (16.6\% for each in Case Study District One, and 14.9\% for each in District Two [15.6\% of total responses]). On the other hand, Targeting was scored lowest (13.3\% in Case Study District One, $15.3 \%$ in District Two [10\% of total responses]). This suggests that some respondents believed that AESs were focused on the requirements of the providers rather than the recipients.
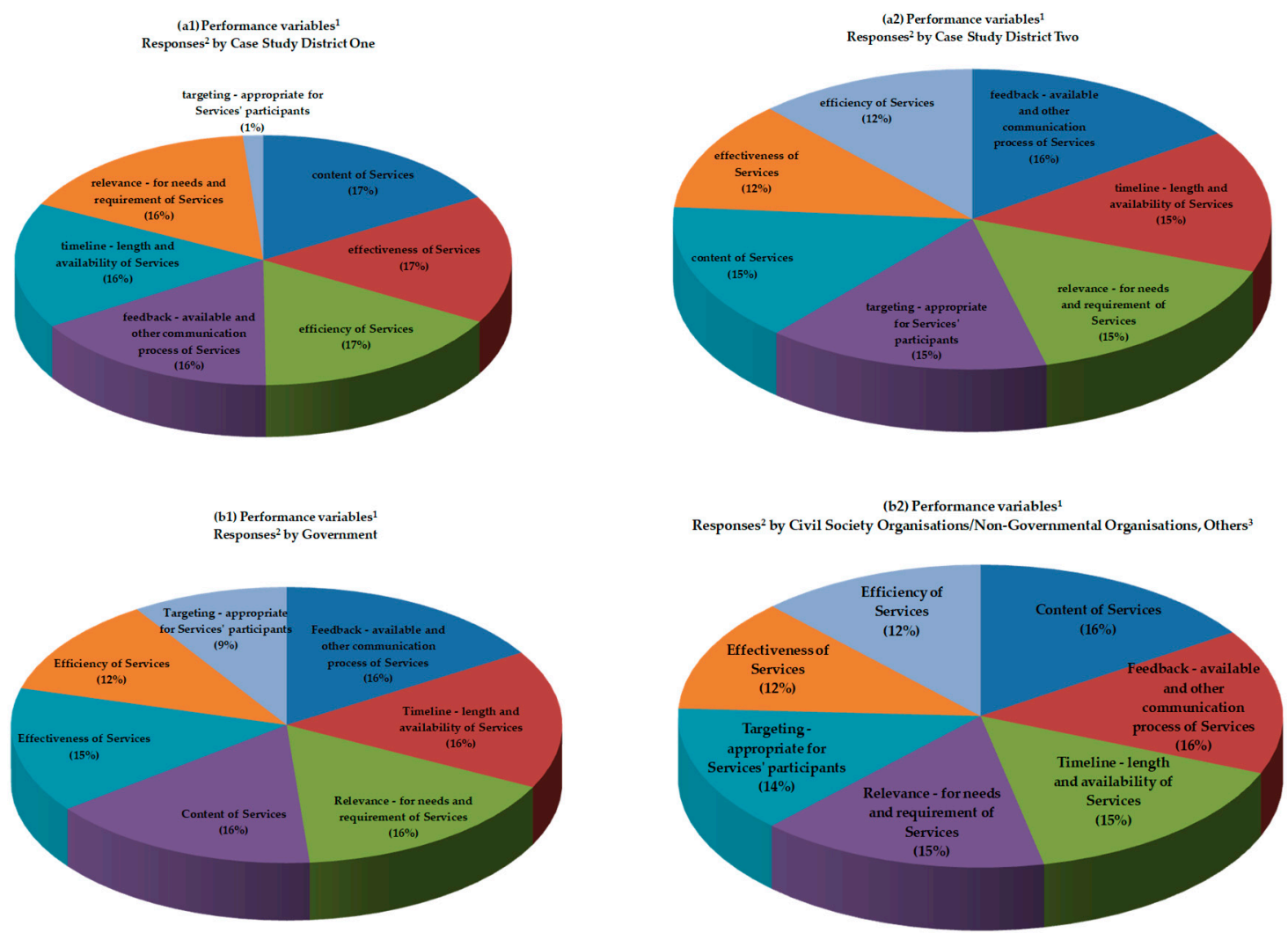

Figure 2. Smallholder farmers' perspectives on Advisory Extension Services by performance variable ${ }^{1}$ (questionnaire survey). (a1,a2) Responses ${ }^{2}$ categorised by Case Study District. (b1,b2) Responses ${ }^{2}$ categorised by service-providing sector. N.B. ${ }^{1}$ See Footnote no. $4 .{ }^{2}$ Some of those interviewed gave multiple responses, therefore figures shown represent the number of responses, not participants.

${ }^{3}$ Others include cultural/religious organisations.

Further comments made by respondents about AES included:

- Timelines: The duration and availability of Advisory Extension Services was short and irregular, and there were insufficient options.

- Feedback: Advisory Extension Services required further following up and monitoring.

4 AES performance variables include Content (accuracy and relevancy of advice), Timeline (duration and availability), Feedback (availability and mode of communication), Relevance (meeting the needs and requirements for recipients/participants), Targeting (appropriacy for recipients/participants), Efficiency (of results obtained against resources invested), and Effectiveness (achievement of objectives) (Birner et al. 2009; European Commission 2006; Faure et al. 2016). 
- Relevance: Influenced by other factors, such as seasonality, topography, and availability of resources.

Smallholder farmers' comments on the impact of AESs were analysed based on the results from the SSQ and FGD\&A, and these were compared against the different variables (positive and less positive) (Figure 3a-d).

(a) Impact of Advisory Extension Services

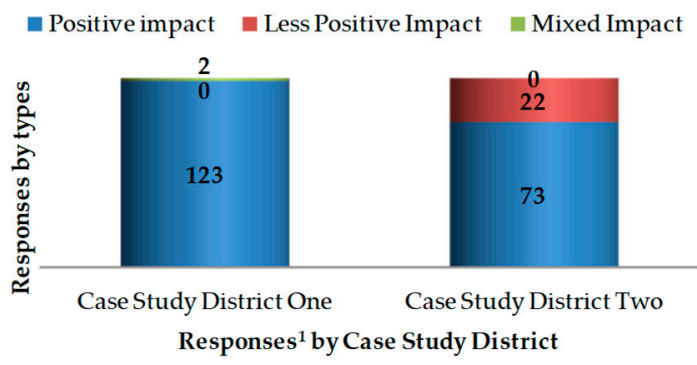

(c) Impact of Advisory Extension Services

- Positive impact $\quad$ - Less Positive Impact $\quad$ Mixed Impact

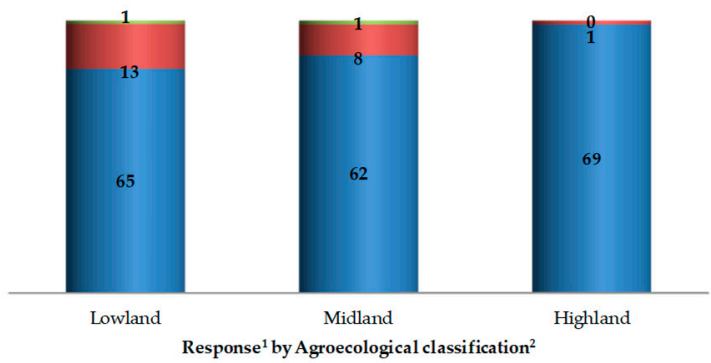

(b) Impact of Advisory Extension Services
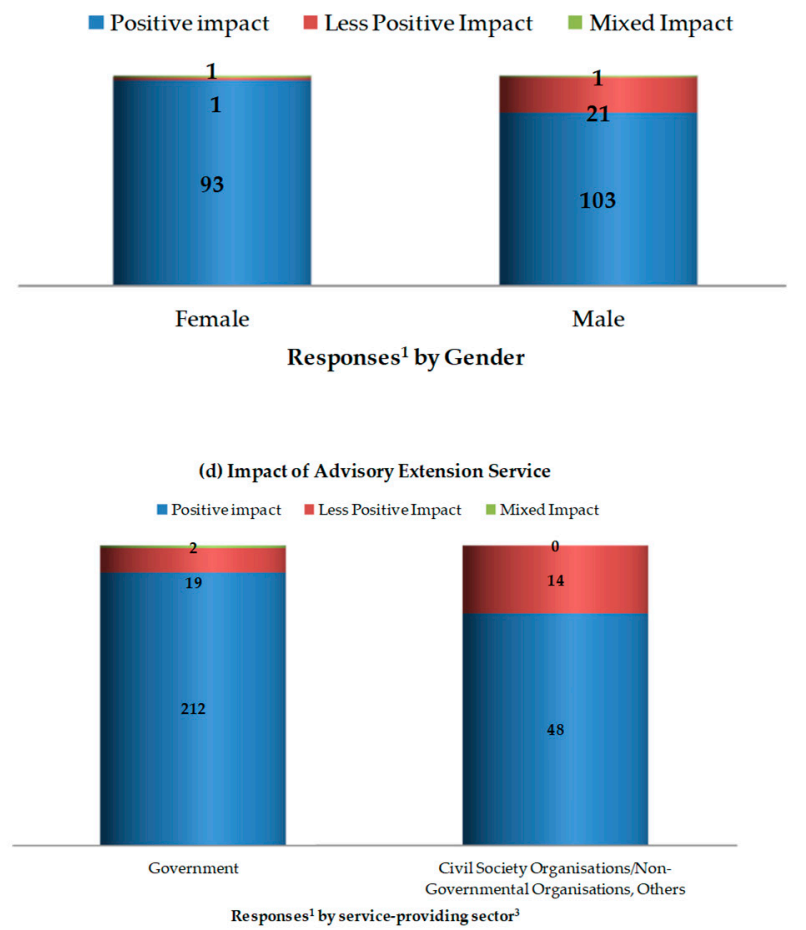

Figure 3. Impact of Advisory Extension Services (positive or less positive ${ }^{1}$ ) (questionnaire survey). (a) Responses categorised by Case Study District. (b) Responses categorised by Gender. (c) Responses categorised by Agroecological classification ${ }^{2}$. (d) Responses categorised by service-providing sector ${ }^{3}$. N.B. ${ }^{1}$ Some of those interviewed gave multiple responses, therefore figures shown represent the number of responses, not participants. ${ }^{2}$ Agricultural classifications: Lowland, altitude 500-1300 m above sea level, Midland, altitude 1300-2200 m above sea level, and Highland, altitude above $2200 \mathrm{~m}$ above sea level. ${ }^{3}$ Service-providing sector, Others include cultural/religious organisations.

The majority of smallholder farmers said that AESs they had received had a positive impact. Economic aspects were the most commonly-identified area on which AESs had an effect, followed by environmental aspects, whereas social aspects were much less commonly mentioned (Table 5). 
Table 5. Common Responses ${ }^{1}$ from Questionnaire Survey/Focus Group Discussion and Activity Participants.

\begin{tabular}{ll}
\hline & \multicolumn{1}{c}{ Examples of Positive Effects of Advisory Extension Services } \\
\hline+ & Production improved in relation to yields and quality of products \\
+ & Living conditions, e.g., housing and health, also improved \\
+ & Training received and knowledge gained helped to improve farming practices and day to day lives \\
+ & Participating in/receiving training for development \\
+ & Involvement in the community for work \\
\hline & $\quad$ Examples of less positive aspects of Advisory Extension Services \\
\hline- & Limited access to resources including tools for farming and transport access (to sell products at markets) \\
- & Some farmers complained that they had to pay for a set amount of fertiliser, which was often more than \\
- & No/little change due to access to water, changing weather conditions, small farm sizes and yield \\
- & Unable to participate in training due to other household commitments \\
- & Unable to cover the cost of livestock treatment/paying too much for fertiliser \\
\hline & $\quad$ Examples of mixed responses concerning Advisory Extension Service performance \\
\hline$+/-$ & No observed effect as Advisory Extension Services has only just begun \\
$+/-$ & Although production increased, changing weather conditions (e.g., dry seasons and precipitation) often \\
$+/-$ & Increased production, but given too much fertiliser \\
$+/-$ & Ongoing and continuous efforts \\
$+/-$ & Neither positive nor negative effects were observed \\
\hline
\end{tabular}

N.B. ${ }^{1}$ Responses by category: Positive (+), less positive (-), and mixed (+/-).

\subsection{Advisory Extension Services-Suitable Approaches, Methods, and Alternative Options}

The research investigated smallholder farmers' viewpoints regarding suitable methods and processes by which they can be best enabled to receive AESs (Table 6).

Table 6. Existing Advisory Extension Service Approaches and Methods identified in the Case Study Locations-Questionnaire Survey/Focus Group Discussion and Activity.

\begin{tabular}{|c|c|c|}
\hline Service-Providing Sector & Approaches ${ }^{1}$ & Methods \\
\hline Public (Government) & Trainings and Visit system & $\begin{array}{c}\text { Training sessions, } \\
\text { workshops, demonstration }\end{array}$ \\
\hline $\begin{array}{c}\text { Civil Society } \\
\text { Organisations/Non-Governmental } \\
\text { Organisations; } \\
\text { Community-/Farmer-based Organisations; } \\
\text { Others (include } \\
\text { cultural/religious organisations) }\end{array}$ & $\begin{array}{l}\text { Trainings and Visit system, Farmer } \\
\text { Field Schools approach }\end{array}$ & $\begin{array}{l}\text { Training sessions, workshops, } \\
\text { demonstration } \\
\text { Field visits, knowledge exchange } \\
\text { and sharing }\end{array}$ \\
\hline
\end{tabular}

One common way in which smallholder farmers received AESs was through formal channels, i.e., services from government and CSOs/NGOs delivered via extension agents or field workforces (known as Development Agents in Ethiopia) Development Agents (DAs). These approaches could be interpreted as a form of the Training \& Visit $(\mathrm{T} \& \mathrm{~V})$ system, with some being delivered via the Farmer Field Schools (FFS) approach. AES methods included attending training sessions or village offices, along with visits by DAs and personnel working at field level.

SSQ respondents also expressed a need for a greater range of services beyond those led by the government, especially in Case Study Village 2.2, where only government-led services were present. Examples of such services they mentioned include post-harvest storage facilities, livestock 
management, and advice on the best way to use fertilisers. They also felt that the absence of alternative service provisions may be unnecessarily slowing their rate of progress in improving the way they live. Examples of desirable alternatives mentioned by smallholder farmers include:

- AES targeting specific socio-demographics (e.g., younger and/or older generations and marginalized groups);

- $\quad$ AES focusing on specific situations, such as climate change and disease prevention; and

- $\quad$ relocation to more productive areas

\section{Discussion}

\subsection{Advisory Extension Services-Access, Participation, Service Delivery, and Impact}

\subsubsection{Smallholder Farmers' Access to and Participation in Advisory Extension Services}

A number of active AES providers were identified in the case study locations.

Smallholder farmers receiving AESs from the government and CSOs/NGOs were common in the case study locations. However, examples of receiving AES through informal channels (i.e., through neighbouring farmers, word of mouth, etc.) were scarce. The use of services depended upon service type, availability, and/or eligibility in that particular location, especially in the case of CSOs/NGOs, CBOs/FBOs, and private institutions. A comparison of smallholder farmers' technology adoption in Ethiopia by Krishnan and Krishnan and Patnam (2014) also revealed that the continuity of technology or knowledge received by farmers was greater when issued through DAs (i.e., formal channels) than through informal channels (e.g., from neighbours). There are also formal and informal rules that influence recipients' practices. These could be due to the formalised system and processes by which public services are considered influential sources of information. Authors such as Lemma and Tesfaye (2016) and Spielman et al. (2011a) have provided insight into the formal and informal channels smallholder farmers may use to access AESs. They concluded that, in order to facilitate technology transfer, recipients require greater interaction and facilitation on the part of service providers.

The nature and extent of smallholder farmers' participation in AES has often been examined in on-farm trials and experimentation for research and technology development processes (Figure 1a,b). Hence, it has rarely been explored in relation to day-to-day AESs. Smallholder farmers' modes of participation are said to depend on sectoral type, country, or continent (Biggs 1989). A combination of collaborative and consultative participation was identified in the case study location, where services were delivered in partnership with providers and participants. Farmer participation through the consultative mode was higher than through the collaborative mode in the case of public institutions, while collaborative mode was more common than consultative mode in the case of CSOs/NGOs. The GoE has been attempting to change the participatory approach by public institutions in response to the implementation of the Participatory Extension System (PES) in 2010 (ATA 2017b; ATA and MoA 2014). However, an investigation into the operational process changes has not been undertaken, especially concerning smallholder farmers' involvement in the PES. Although a number of good examples have been seen in other parts of the country, this system has not been widely implemented nationally (ATA 2017b). Therefore, smallholder farmers' participation in ordinary day-to-day AESs requires an insight investigation. It has also been suggested that farmer participation in AESs needs to extend beyond dissemination and implementation, and that levels of participation can influence the outcome and continuation of service received (Elias et al. 2016; Jonfaa et al. 2003). Smallholder farmers' engagement throughout the operations of AESs could eventually assist in developing awareness, capacity-building, decision-making, and effective collective actions (Biggs 1990; Douthwaite et al. 2009; Hellin et al. 2008; Mohan and Stokke 2000). Furthermore, active smallholder farmers' engagement through such integrated participatory approaches is said to improve their empowerment, social capacity, and mobilisation at community level. (Belay 2002; Hagmann et al. 1999; 
Mohan and Stokke 2000). In order for service provision to have a long-lasting impact, providers should focus on core issues of economic and social development, along with self-governance, equity, and equality for the rural communities. (Biggs 1990, 2008; Hagmann et al. 1999).

\subsubsection{Smallholder Farmers' Responses Concerning Service Delivery and the Impact of Advisory} Extension Services

The opinions of smallholder farmers are one of the key considerations that should be taken into account in service provision delivery, as it is important to understand their experiences and views in order to provide services which are both relevant and practical. Concerning the effects of AES delivery, smallholder farmers raised concerns related to input packages, such as oversupply and repayment of inputs (e.g., fertilisers), and imbalances in prices and supply.

A number of variables can be applied when evaluating the performance of AES in relation to the goals of providers, see Footnote no. 3 and Introduction). Research carried out by Croppenstedt et al. (2003) and Jona and Terblanche (2015) illustrated multiple factors associated with aspects cited by farmers as challenges and constraints. Such interlinked factors included resource availability and access, together with the frequency, reliability, and relevancy of AESs. In addition, smallholder farmers face a number of overriding challenges in accessing certain resources in order to improve their productivity and welfare standards. These include credit access and limited labour and market opportunities (Croppenstedt et al. 2003). Moreover, smallholder farmers indicated their preference for regular and ongoing AESs, enabling the facilitation of regular consultations and frequent feedback on their practices.

The responses of smallholder farmers to AES delivery differed depending on the providing sector (e.g., public, CSOs/NGOs, etc.). Jona and Terblanche (2015) stated that CSOs/NGOs and private institutions offer a more relevant and better-quality AES compared to other sectors. The quality of AES delivered may also influence smallholder farmers' continuation of new practises they have learned (e.g., farming techniques, use of new fertilisers, seeds) (Croppenstedt et al. 2003; Elias et al. 2016; Spielman et al. 2011b). Therefore, in order for the content of an AES to be considered appropriate, it must be comprehensible and practical for recipients. When AESs do not meet these criteria, it is unlikely that smallholder farmers will be able to successfully adopt what they have learned (Croppenstedt et al. 2003; Jona and Terblanche 2015).

Smallholder farmers' responses to the impacts of AESs were examined (Figure 3 and Table 3 ). The number of positive responses concerning the impact of AESs was higher than the less positive ones, and impacts mentioned were related to economic and social aspects, whether directly or indirectly. Studies from different parts of Ethiopia, other East African countries (Uganda, Kenya, and Tanzania), and South Africa reported a range of impacts, including on productivity and product quality at farm level, job creation, improved diets, gender equality, empowerment, and environmental conditions (Assefa 2014; Benin et al. 2011; Davis et al. 2012).

\subsection{Advisory Extension Services—Suitable Approaches, Methods, and Alternative Options}

\subsubsection{Existing Approaches and Methods}

Smallholder farmers' responses to existing and suitable AES approaches, methods, and options were investigated (Table 4). The approaches and methods of existing AES identified for the case study locations were predominantly via Transfer of Technology (ToT) through the T\&V system, together with FFS training carried out by DAs and field workers at village level. Despite the GoE introducing the PES, which calls for farmers to be organised into development groups or social networks ${ }^{5}$ within their

5 These groups or networks consist of an average of 25-30 farmers, and one in five groups have one lead model farmer and five follower farmers. 
villages, this approach has not been fully implemented nationally (ATA 2017b). Both the performance and type of service available may have an impact on smallholder farming households, but different responses to the question may be given if smallholder farmers had more opportunities to participate in experiences such as knowledge sharing and field visits. (Other factors also affected whether practices were continued, such as seasonal changes and the perceived usefulness of the practice).

\subsubsection{Suitable Approaches, Methods, and Alternative Options}

Smallholder farmers' responses concerning the most suitable methods and approaches to delivering AESs (along with possible alternatives) were influenced by their socio-demographic status and the agro-ecological conditions they live under.

Smallholder farmers in the case study locations frequently mentioned a need for accessing a wider range of resources (such as savings and credit schemes). Access to resources such as financial assistance is a common challenge for farmers, especially small-scale and marginalized farmers (see (Yadav and Sharma 2015)). Macro and micro constraints linked to finance and assets such as land ownership, size, and productivity (Baffoe and Matsuda 2015; Yadav and Sharma 2015) showed how farmers' performance, behaviour, and technical efficiency (in both their farming and off-farm activities) vary according to status, and this affects their credit allocation. A lack of credit access may affect a range of activities, not only in relation to farm productivity, but also to household needs and the assets necessary to increase off-farm activity and diversification (Baffoe and Matsuda 2015).

Moreover, there were also differences in smallholder farmers' responses within the same region in the case study locations. Such differences demonstrate how the heterogeneous nature of smallholder farmers (such as their existing assets and abilities) can be related to challenges or constraints which may affect their ability to diversify further. For instance, Alobo Loison (2015) concluded that diversification and off-farm activities were often successfully achieved by wealthier farmers since they have more assets and opportunities. Similarly, only a minority of farmers in Rwanda were wealthy enough to specialise in marketable crops and succeed in producing yield and income from their implementation of modern seeds and access to input and credit (Dawson et al. 2016).

The research findings suggest that, in order for smallholder farmers to be able to maintain and improve their farming practices and quality of living conditions, efforts should be made to increase their awareness of the existing interventions and alternative options available. Greater understanding of both existing interventions and priority issues would help them to identify areas in need of AES intervention, which in turn could enable providers to develop new services tailored to their target recipients. Furthermore, for smallholder farmers to benefit from alternative options, greater links between service providers and farmers need to be established and processes formulated. This could be achieved by creating a communication platform between the two in which smallholder farmers are given the opportunity to express their needs, exchange feedback, and identify pathways for development and/or impact.

For the service providers, their responsibilities include delivering services which are both suitable and necessary for smallholder farmers, and they should be accountable for this. The governmental workforces and village/community leaders also play a vital role at the local level, and at the district level are accountable for assessing and implementing the requirements of the villages they administer. In establishing greater communication and collaboration between farmers, not only will services be able to reach more farmers and the burden of geographical barriers be reduced, but there are also likely to be indirect beneficiaries and impacts as a result (Faure et al. 2016; Spielman et al. 2011a, 2011b; Rajalahti and Swanson 2010).

\section{Materials and Methods}

An exploratory inductive approach was adopted, combined with collating a wide range of qualitative and quantitative information and datasets from both primary and secondary resources. This case-study based research project research project was undertaken in two Case Study Districts 
(with three Case Study Villages in each) to examine the situation of rural farming households of the Gamo community in southern Ethiopia. The range of elements of AES performance explored was based on a number of variables (e.g., content, timeline, feedback, relevance, target, efficiency, and effectiveness) (Benin and Johnson 2008; Birner et al. 2009; European Commission 2006; Faure et al. 2016; Martin et al. 2011). In the case of smallholder farmer participation in AES, this was based on a breakdown of methods and schema suggested by Biggs (1989, pp. 3-4) and divided into categories of contracted, consultative, collaborative, or collegiate modes (Footnote no 4).

Mixed methods and tools were used for the data collection, including a Semi-Structured Questionnaire Survey (SSQ), Focus Group Discussion \& Activity (FGD\&A), Key Informant Interviews (KIIs), and document and observation analyses. Sample respondents and participants included members of farming households (SSQ = 270, FGD\&A = 72) and personnel working in the rural agricultural sector (KIIs = 30), such as Development Agents, extension experts, and training and service providers. A range of sampling techniques was used in order to select the Case Study Districts and Villages, respondents, participants, and informants, including purposive and stratified random sampling for the SSQ, stratified random sampling for the FGD\&A, and purposive and snowballing sampling for the KIIs. The fieldwork data collected was analysed using SPSS and Nvivo to generate both quantitative and qualitative information and representations.

The main limitation of the materials and methods used (and the overall research project) is the 'credibility of generalisation' related to the location-specific findings. However, the authors believe that the outcome of the research project provides valuable insight into participants' viewpoints on service provisions, and that this aspect has often been neglected in the past.

\section{Conclusions}

This case study-based research project aimed to investigate AESs from the perspectives of the recipients (i.e., smallholder farmers). The majority of these were subsistence farmers in rural highland areas, some of whom engaged in a variety of off-farm and non-farming activities as one possible means of improving their livelihoods. Many of these farmers had received or participated in AESs in the hope of improving their existing farming practices and standard of living.

The research undertaken revealed that farmers' participation in the process of AES was mainly through a combination of two modes: Consultative (whereby advice and services are decided in consultation with the provider), and collaborative (through partnership between service providers and recipients). The farmers rated AES performance based on variables associated with feedback (i.e., availability and mode of communication), timeline (i.e., duration and availability), and relevance (to the needs and requirements of recipients/participants). Desirable additions or alternatives to existing services mentioned by farmers included greater access to resources such as savings and credit, and increased market and off-farm opportunities.

However, a combination of both farming and off-farm activities is only likely to be effective if smallholder farmers are given access to resources such as credit and markets. The successful dissemination and scaling of AES could be achieved through the establishment of CBOs/FBOs at community-level, and smallholder farmers' engagement within these organisations would help in tailoring services to particular locations. Furthermore, there is a potential for service providers to work more closely with model or innovative farmers.

A number of implications and recommendations can be drawn from this research. One is that greater use should be made of informal channels. The evidence suggests that community engagement and participation in activities by smallholder farmers could ease the burden of overstretched development agents and field workforces. Identifying a model for innovative farmers in the community able to deliver advice and support is also recommended. In addition, throughout the process of AES development and dissemination, participation and collaboration among service providers and smallholder farmers should be encouraged. Smallholder farmers' involvement is likely to be far higher 
if they are given the opportunity to contribute equally alongside providers from the very beginning, as well as throughout the course of the process.

Further projects focusing upon understanding smallholder farmers' perspectives would undoubtedly be beneficial. In particular, in-depth longitudinal and ethnographic studies could be highly valuable in identifying the most suitable AES approaches for particular locations.

The findings also suggest a continuous need for further study and increased tailoring of AES to specific local contexts, as well as for greater resource access and encouragement of farmer participation throughout the process. Furthermore, the mobilisation and strengthening of AES through social learning and engagement is essential in order to achieve an overall transformation in social, human, and economic development at local community level and beyond. These findings highlight the importance of placing the farmer and their needs at the centre of the design and delivery of extension and communication services, with project and programmes designed to enable the voice and meaningful participation of farmers in order to achieve the livelihood and agricultural production goals desired by both the project implementers and the participating farmers. Understanding how farmers perceive "success" in AES interventions helps us to understand how to improve their design and implementation, to better address the complex needs of rural livelihoods. Embedding AES in contextual communication systems, which are meaningful for participating farmers, reinforces the potentially positive impact of such interventions. Fundamentally, the results of this study highlight the importance if placing the farmer at the centre of AES design to achieve the desired outcomes.

Author Contributions: Conceptualization, M.D.; methodology, M.D.; software, M.D.; validation, M.D.; formal analysis, M.D.; investigation, M.D.; resources, M.D.; data curation, M.D.; writing—original draft preparation, M.D.; writing-review and editing, M.D. and S.C.; visualization, M.D.; supervision, S.C. All authors have read and agreed to the published version of the manuscript.

Funding: This research received no external funding.

Conflicts of Interest: The authors declare no conflict of interest.

\section{Abbreviations}

The following abbreviations are used in this manuscript:

$\begin{array}{ll}\text { AES } & \text { Advisory Extension Services } \\ \text { CBOs/FBOs } & \text { Community-/Farmer-Based Organisations } \\ \text { CSOs/NGOs } & \text { Civil Society Organisations/Non-Governmental Organisations } \\ \text { DAs } & \text { Development Agents } \\ \text { EPRDF } & \text { Ethiopian People's Revolutionary Democratic Front } \\ \text { FFSs } & \text { Farmer Field Schools } \\ \text { FGD\&A } & \text { Focus Group Discussion and Activity } \\ \text { GoE } & \text { Government of Ethiopia } \\ \text { GTP } & \text { Growth and Transformation Plan } \\ \text { KIIs } & \text { Key Informant Interviews } \\ \text { PES } & \text { Participatory Extension System } \\ \text { PIF } & \text { Policy and Investment Framework } \\ \text { SNNPR } & \text { Southern Nations', Nationalities' and Peoples' Region } \\ \text { SSQs } & \text { Semi-Structured Questionnaire } \\ \text { T\&V } & \text { Training and Visit } \\ \text { ToT } & \text { Transfer of Technology }\end{array}$

\section{References}

Alobo Loison, Sarah. 2015. Rural livelihood diversification in sub-Saharan Africa: A literature review. The Journal of Development Studies 51: 1125-38. [CrossRef]

Anderson, Jack. R., and Gershon Feder. 2004. Agricultural Extension: Good Intentions and Hard Realities. World Bank Research Observer 19: 41-60. [CrossRef] 
Assefa, Amanuel. 2014. A Pathway to A Lasting Partnership: Prolinnova-Ethiopia's Decade of Experience with Innovative Farmers. Addis Ababa: PROLINNOVA-Ethiopia.

ATA. 2017a. Transformation Agenda; Addis Ababa: Agricultural Transformation Agency. Available online: http://www.ata.gov.et/\# (accessed on 30 June 2017).

ATA. 2017b. Ethiopia's Agricultural Extension System: Vision, Systemic Bottlenecks and Priority Interventions. Addis Ababa: Agricultural Transformation Agency.

ATA, and MoA. 2014. National Strategy for Ethiopia's Agricultural Extension System: Vision, Systemic Bottlenecks and Priority Interventions. Addis Ababa: Agricultural Transformation Agency and Ministry of Agriculture.

Baffoe, Gideon, and Hirotaka Matsuda. 2015. Understanding the Determinants of Rural Credit Accessibility: The Case of Ehiaminchini, Fanteakwa District, Ghana. Journal of Sustainable Development 8: 183. [CrossRef]

Bayu, Teshome Yirgu. 2012. The Guge mountain range: Gis application for mountain resource degradation and rural livelihood. Journal of Research in Environmental Science and Technology 1: 91-99.

Belay, Kassa. 2002. Constraints to agricultural extension work in Ethiopia: The insiders' view. South African Journal of Agricultural Extension 31: 63-79.

Benin, Samuel, and Michael Johnson. 2008. Monitoring and Evaluation (MEE) System for the Comprehensive Africa Agriculture Development Programme (CAAP) (No. H04279). Colombo: International Water Management Institute.

Benin, Samuel, Ephraim Nkonya, Geresom Okecho, Joseé Randriamamonjy, Edward Kato, Geofrey Lubade, and Miriam Kyotalimye. 2011. Returns to spending on agricultural extension: The case of the National Agricultural Advisory Services (NAADS) program of Uganda. Agricultural Economics 42: 249-67. [CrossRef]

Berhanu, Kassahun. 2012. The Political Economy of Agricultural Extension in Ethiopia: Economic Growth and Political Control. Brighton: Institute of Development Studies.

Biggs, Stephen D. 1989. Resource-Poor Farmer Participation in Research: A Synthesis of Experiences from Nine National Agricultural Research Systems. Hague Países Bajos, No. 3. Hague: OFCOR-Comparative Study.

Biggs, Stephen D. 1990. A multiple source of innovation model of agricultural research and technology promotion. World Development 18: 1481-99. [CrossRef]

Biggs, Stephen. 2008. The lost 1990s? Personal reflections on a history of participatory technology development. Development in Practice 18: 489-505. [CrossRef]

Birner, Regina, Kristin Davis, John Pender, Ephraim Nkonya, Ponniah Anandajayasekeram, Javier Ekboir, Adiel Mbabu, David J. Spielman, Daniela Horna, Samuel Benin, and et al. 2009. From Best Practice to Best Fit: A Framework for Designing and Analyzing Pluralistic Agricultural Advisory Services Worldwide. Journal of Agricultural Education and Extension 15: 341-55. [CrossRef]

CBD. 2014. Ethiopia-Country Profile, Status and Trends of Biodiversity. Montreal: CBD (Convention on Biological Diversity) Secretariat. Available online: http://www.cbd.int/countries/profile/default.shtml?country=et\# status (accessed on 30 November 2014).

Christoplos, Ian, Peta Sandison, and Sanne Chipeta. 2012. Guide to Evaluating Rural Extension. Lindau: Global Forum for Rural Advisory Services.

Croppenstedt, Andre, Mulat Demeke, and Meloria M. Meschi. 2003. Technology adoption in the presence of constraints: The case of fertilizer demand in Ethiopia. Review of Development Economics 7: 58-70. [CrossRef]

Davis, Kristin, Ephraim Nkonya, Edward Kato, Daniel Ayalew Mekonnen, Martins Odendo, Richard Miiro, and Jackson Nkuba. 2012. Impact of Farmer Field Schools on Agricultural Productivity and Poverty in East Africa. World Development 40: 402-13. [CrossRef]

Dawson, Neil, Adrian Martin, and Thomas Sikor. 2016. Green revolution in Sub-Saharan Africa: Implications of imposed innovation for the Wellbeing of rural smallholders. World Development 78: 204-18. [CrossRef]

Douthwaite, Boru, Nathalie Beaulieu, Mark Lundy, and Dai Peters. 2009. Understanding how participatory approaches foster innovation. International Journal of Agricultural Sustainability 7: 42-60. [CrossRef]

Elias, Asres, Makoto Nohmi, Kumi Yasunobu, and Akira Ishida. 2016. Farmers' Satisfaction with Agricultural Extension Service and Its Influencing Factors: A Case Study in North West Ethiopia. Journal of Agricultural Science and Technology 18: 39-53.

European Commission. 2006. Evaluation Methods for the European Union's External Assistance. Luxemburg: Office for Official Publications of the European Communities. 
Faure, Guy, Kristin E. Davis, Catherine Ragasa, Steven Franzel, and Suresh C. Babu. 2016. Framework to Assess Performance and Impact of Pluralistic Agricultural Extension Systems: The Best-Fit Framework Revisited. Washington: International Food Policy Research Institute, vol. 1567.

Fenta, Tesfahun, and Amanuel Assefa. 2009. Harnessing local and outsiders' knowledge: Experiences of a multi-stakeholder partnership to promote farmer innovation in Ethiopia. Innovation Africa: Enriching Farmers' Livelihoods 2009: 90-103.

Gebremedhin, Berhanu, Dirk Hoekstra, and Azage Tegegn. 2006. Commercialization of Ethiopian Agriculture: Extension Service from Input-Supplier to Knowledge Broker and Facilitator. Addis Ababa: International Livestock Research Institute.

Hagmann, Jurgen, Edward Chuma, Kudakwashe Murwira, and Mike Connolly. 1999. Putting Process into Practice: Operationalizing Participatory Extension. Agricultural research and Extension Network Paper no. 94. London: Overseas Development Institute.

Hellin, Jon, Mauricio R. Bellon, Lone Badstue, John Dixon, and Roberto La Rovere. 2008. Increasing the impacts of participatory research. Experimental Agriculture 44: 81-95. [CrossRef]

Jona, Cecilie Ndeshipanda, and Stephanus Esaias Terblanche. 2015. Farmers' perception on contact frequency, adequacy, relevance and quality of agriculture support services (Ass) in Oshikoto region in Namibia. South African Journal of Agricultural Extension 43: 107-21.

Jonfaa, Ejigu, Barry Pound, Endreas Getac, Ousman Sururd, and Furgassa Bedadae. 2003. Institutionalisation of Farmer Participatory Research in Southern Ethiopia: A joint learning experience. In Advancing Participatory Technology Development: Case studies on integration into agricultural research, extension and education. Edited by Wettasinha Chesha, Laurens van Veldhuizen and Ann Waters-Bayer. Silang: IIRR/ETC Ecoculture/CTA, pp. 237-54.

Kassa, Habtemariam. 2008. Agricultural extension in Ethiopia: Historical evolution, relevant policies, and challenges. In Digest of Ethiopia's National Policies, Strategies and Programs. Forum for Social Studies 2008: 153-75.

Krishnan, Pramila, and Manasa Patnam. 2014. Neighbors and extension agents in Ethiopia: Who matters more for technology adoption? American Journal of Agricultural Economics 96: 308-27. [CrossRef]

Lemma, Mamusha, and Beamlak Tesfaye. 2016. From research-extension linkages to innovation platforms: Formative history and evolution of multi-stakeholder platforms in Ethiopia. Journal of Agricultural Economics, Extension and Rural Development 4: 496-504.

Martin, Adrienne, Sabine Gundel, Essie Apenteng, and Barry Pound. 2011. Review of Literature on Evaluation Methods Relevant to Extension. Lindau: Global Forum for Rural Advisory Services.

MoANR. 2017. Overview of the Ministry; Addis Ababa: Ministry of Agriculture and Natural Resource, MoANR (formally Ministry of Agriculture and Rural Development, MoARD). Available online: http://www.moa.gov. et/web/pages/overview-of-the-ministry (accessed on 5 May 2017).

Mohan, Giles, and Kristian Stokke. 2000. Participatory development and empowerment: The dangers of localism. Third World Quarterly 21: 247-68. [CrossRef]

Oakley, Peter, and Christopher Garforth. 1997. Guide to Extension Training (No. 11). Rome: Food and Agriculture Organization of the United Nations.

Poulton, Colin, Andrew Dorward, and Jonathan Kydd. 2010. The future of small farms: New directions for services, institutions, and intermediation. World Development 38: 1413-28. [CrossRef]

Pretty, Jules N. 1995. Regenerating Agriculture Policies and Practices for Sustainability and Self-Reliance. Washington: Joseph Henry Press.

Rahmato, Dessalegn. 1984. Agrarian Reform in Ethiopia. Uppsala: Scandinavian Institute of African Studies.

Rajalahti, Riikka, and Burton E. Swanson. 2010. Strengthening Agricultural Extension and Advisory Systems: Procedures for Assessing, Transforming and Evaluating Extension Systems. Washington: World Bank.

Rajalahti, Riikka, Johannes Woelcke, and Eija Pehu. 2005. Monitoring and Evaluation for World Bank Agricultural Research and Extension Projects: A Good Practice Note. Agriculture and Rural Development Discussion Paper No. 20. Washington: World Bank.

Röling, Niels. 1988. Extension Science: Information Systems in Agricultural Development. Cambridge: Cambridge University Press. 
Samberg, Leah H., Carol Shennan, and Erika S. Zavaleta. 2010. Human and Environmental Factors Affect Patterns of Crop Diversity in an Ethiopian Highland Agroecosystem. The Professional Geographer 62: 395-408. [CrossRef]

Spielman, David J., Kristin Davis, Martha Negash, and Gezahegn Ayele. 2011a. Rural innovation systems and networks: Findings from a study of Ethiopian smallholders. Agriculture and Human Values 28: 195-212. [CrossRef]

Spielman, David J., Dawit Kelemwork, and Dawit Alemu. 2011b. Seed, Fertilizer, and Agricultural Extension in Ethiopia. Ethiopia Strategy Support Program II (ESSP II), International Food Policy Research Institute, ESSP II Working Paper 020. Washington: International Food Policy Research Institute.

Swanson, Burton E., Robert P. Bentz, and Andrew J. Sofranko, eds. 1998. Improving Agricultural Extension: A Reference Manual, 3rd ed. Rome: Food and Agriculture Organization of the United Nations.

Wigboldus, Seerp, and Cees Leeuwis. 2013. Towards Responsible Scaling up and out in Agricultural Development: An Exploration of Concepts and Principles. Wageningen: Centre for Development Innovation, Wageningen Research Centre and University.

Yadav, Priyanka, and Anil K. Sharma. 2015. Agriculture Credit in Developing Economies: A Review of Relevant Literature. International Journal of Economics and Finance 7: 219. [CrossRef]

Zuurbier, Peter J. P. 1984. De Besturing en Organisatie van de Landbouwvoorlichtingsdienst. Ph.D. Thesis, Agricultural University, Wageningen, The Netherlands.

(C) 2020 by the authors. Licensee MDPI, Basel, Switzerland. This article is an open access article distributed under the terms and conditions of the Creative Commons Attribution (CC BY) license (http://creativecommons.org/licenses/by/4.0/). 